\title{
The deglacial history of surface and intermediate water of the Bering Sea
}

\author{
Mea S. Cook* \\ MIT-WHOI Joint Program in Marine Geology 8 Geophysics, Woods Hole \\ Oceanographic Institution, Woods Hole, Massachusetts 02543, USA \\ Lloyd D. Keigwin \\ Department of Marine Geology $\&$ Geophysics, Woods Hole Oceanographic \\ Institution, Woods Hole, Massachusetts 02543, USA \\ Constance A. Sancetta \\ 1637 Irvin Street, Vienna, Virginia 22182, USA
}

\begin{abstract}
The lithology of deglacial sediments from the Bering Sea includes intervals of laminated or dysaerobic sediments. These intervals are contemporaneous with the occurrence of laminated sediments from the California margin and Gulf of California, which suggests widespread low-oxygen conditions at intermediate depths in the North Pacific Ocean. The cause could be reduced intermediate water ventilation, increased organic carbon flux, or a combination of the two. We infer abrupt decreases of planktonic foraminifer $\delta^{18} \mathrm{O}$ at $14,400 \mathrm{y} \mathrm{BP}$ and $11,650 \mathrm{y} \mathrm{BP}$, which may be a combination of both freshening and warming. On the Shirshov Ridge, the abundance of sea-ice diatoms of the genus Nitzschia reach local maxima twice during the deglaciation, the latter of which may be an expression of the Younger Dryas. These findings expand the extent of the expression of deglacial millennial-scale climate events to include the northernmost Pacific.
\end{abstract}

Key words: anoxic sediments, deglaciation, diatoms, foraminifera, oxygen isotope stratigraphy, Bering Sea

\footnotetext{
* Corresponding author.

Email address: meacook@mit.edu (Mea S. Cook).
} 


\section{Introduction}

Water mass tracer proxies measured from the most intense cold events of the last deglaciation, Heinrich Event 1 and the Younger Dryas (YD), are consistent with a reduction in the strength of the Atlantic meridional overturning circulation (MOC) (Boyle and Keigwin, 1987; Zahn et al., 1997; Vidal et al., 1997; McManus et al., 2004). Because of the large transport of heat associated with the MOC, $60 \%$ of the Northern Hemisphere midlatitude poleward ocean heat transport takes place in the Atlantic (Talley, 2003), which is half the size of the Pacific. There is no analogous circulation like the MOC in the Pacific today, where heat transport is dominated by that associated with the shallow wind-driven gyre circulation. The lack of deep or intermediate convection is attributed to the low salinity of North Pacific surface waters, which even at their freezing point, are not dense enough to convect (Warren, 1983; Emile-Geay et al., 2003).

In the modern North Pacific, freshening and an increase in apparent oxygen utilization of NPIW in the last $60 \mathrm{y}$ are linked to hydrographic changes in the Western Subarctic Gyre (WSAG) and the Okhotsk Sea (Andreev and Watanabe, 2002; Joyce and Dunworth-Baker, 2003; Hill et al., 2003) demonstrating a link between surface and intermediate water physical properties. From the presence of CFCs in the deepest Bering Sea Basin (Warner and Roden, 1995), there is a very small amount of deep water formation occurring there today. Deep water in the rest of the North Pacific originates from the Southern Ocean (Roden, 1995).

From geochemical proxies of nutrients, dissolved oxygen, temperature, and salinity within intermediate (Keigwin and Jones, 1990; Behl and Kennett, 1996; Zheng et al., 2000; Keigwin, 1998; Ahagon et al., 2003) and deep water (Herguera et al., 1992; Lund and Mix, 1998; Matsumoto et al., 2002), it is hypothesized that the ventilation of the intermediate and the deep Pacific water masses was higher in the past. This implies that the balance of freshwater and salt in the ocean basins would have been significantly different than today, possibly with greater oceanic heat transport in the Pacific. Unfortunately, detailed interpretation of the paleo-geochemical evidence at most open ocean sites is not possible because of low sediment accumulation rates.

The high-resolution records in laminated sediments from anoxic basins from the California coast and the Gulf of California have been extensively studied (Behl and Kennett, 1996; Zheng et al., 2000; van Geen et al., 2003; Ortiz et al., 2004). But because productivity in California margin anoxic basins is a function of coastal upwelling, it is difficult to distinguish between reduced ventilation and local increase in export production as the cause of laminations. 
The Bering Sea's proximity to the Okhotsk Sea, which is the source of the precursor to modern NPIW, and its position as the gateway between the North Pacific and the Arctic make it a desirable place to study Pacific paleoclimatology. In addition, coring of the thickly sedimented continental margin (Carlson and Karl, 1988) and aseismic ridges allows for high resolution studies.

On the USCGC Healy in summer, 2002, we collected new sediment cores from 3 regions: Bowers Ridge, an aseismic ridge in south-central Bering Sea, Umnak Plateau, on the southeast end of the continental slope, and between the Pervenets and Navarin Canyons, on the northwest end of the slope (Figure 1, Table 1). Our preliminary data indicate many of these cores have very high sediment accumulation rates and good calcium carbonate $\left(\mathrm{CaCO}_{3}\right)$ preservation and will provide an excellent record of rapid climate variability over the last complete glacial cycle. Most coring locations are far enough away from continental land masses to be less influenced by coastal upwelling.

Due to the low $\mathrm{CaCO}_{3}$ accumulation rates endemic to the Pacific, most of the previous marine paleoclimatological work in the Bering Sea region is based on siliceous microfossil abundances (Zhuze, 1962; Sancetta and Robinson, 1983; Sancetta et al., 1985; Morley and Robinson, 1986; Starratt, 1993). In particular, \% Nitzschia indicates greater sea ice coverage in the last glacial period along the eastern shore of the Bering Sea, including the Pervenets Canyon region and the Umnak Plateau. Modern distribution of Nitzschia is consistent with observed sea ice extent, where the southern slope including the Umnak Plateau is relatively ice-free.

From the abundance of low-oxygen benthic foraminifer species, near Pervenets Canyon, Starratt (1995) inferred that the oxygen minimum zone (OMZ) fluctuated in the past. Gorbarenko (1996), in the Okhotsk and Bering Seas, found 2 episodes of deglacial freshening of surface water associated with increases in $\% \mathrm{CaCO}_{3}, \%$ opal, and \% organic carbon $\left(\mathrm{C}_{\mathrm{org}}\right)$. However, these data are difficult to correlate with the global observations from the last glacial maximum (LGM) and deglaciation because of poor age control.

In this paper, we will discuss our observations of the deglaciation in the Bering Sea, incorporating previously unpublished diatom and foraminifer $\delta^{18} \mathrm{O}$ from 3 older cores: RC14-121 (R/V Conrad, Umnak Plateau), VINO19-12GGC (R/V Vinogradov, Bowers Ridge), and ANTP-42PC (R/V Melville, Shirshov Ridge). Our synthesis will show that the changes we observe were widespread, not only within the Bering Sea, but probably throughout the open North Pacific. 


\section{Bering Sea hydrography}

The Bering Sea lies between the Aleutian Islands to the south, Siberia to the northwest, and Alaska to the northeast, and consists of a broad continental shelf (50-150 m deep) and a deep basin (<4000 m deep) (Figure 1). The principal surface circulation in the basin is a cyclonic gyre, whose western boundary current is the southward flowing Kamchatka Current. Alaskan Stream water flows northward through passes between the Aleutian Islands and is incorporated into this gyre circulation. The Bering Slope Current (BSC), which flows along the edge of the continental shelf, marks the eastern edge of the gyre.

On the shelf, the principal surface flow is northward, with net northward flow through the Bering Strait, which is $85 \mathrm{~km}$ wide and $50 \mathrm{~m}$ deep (Schumacher and Stabeno, 1998). Water from the Bering Sea is relatively low salinity and rich in nutrients, and is an important component of the upper halocline in the Arctic (Cooper et al., 1997). With reduced sea level $(\sim-130 \mathrm{~m})$ during the last glacial period, the continental shelf was subaerialy exposed, isolating the North Pacific from the Arctic and North Atlantic. The Bering Strait reopened during the deglaciation, no later than $11,000{ }^{14} \mathrm{C}$ y before present $(\mathrm{BP})(\geq \sim 13,000 \mathrm{y}$ BP) (Elias et al., 1997).

To the south, the Bering Sea is connected to the North Pacific through various straits and passes, the largest of which are (from west to east) Kamchatka Strait (4420 m), Near Strait (2000 m), Buldir Pass (640 m), Amchitka Strait (1155 m), and Amutka Pass (430 m) (Figure 1). Physical properties of water across the Aleutian Islands diverge deeper than $2000 \mathrm{~m}$, indicating relatively unimpeded exchange between the Bering Sea and North Pacific at and above the depth of Near Strait. Constricted exchange of deep water occurs through Kamchatka Strait. In the eastern Bering Sea, northward flow through the Unimak Pass ( $<80 \mathrm{~m}$ deep) is the major conduit between the North Pacific and the shelf (Stabeno et al., 1999). At the LGM, this pass was closed, but exchange through the remainder of the Aleutian Arc was probably not significantly affected.

NPIW is formed by cabbeling of the northward flowing warm and salty Kuroshio Current and the southward flowing cold and fresh Oyashio Current waters where they meet east of Hokkaido, Japan (Yasuda, 1997; You, 2003). In the North Pacific, the core of NPIW approximately follows the $26.8 \sigma_{\theta}$ potential density surface, and is associated with a salinity minimum and oxygen maximum. The density of the core of NPIW is determined by Okhotsk Sea Mode Water (OSMW), the product of brine rejection during winter sea ice formation. OSMW flows out of the Okhotsk Sea through the Kuril Islands, and mixes with WSAG water, forming Oyashio Current water. Today, NPIW is found at 200-400 $\mathrm{m}$ in the Bering Sea (Macdonald et al., 2001). The water mass at 


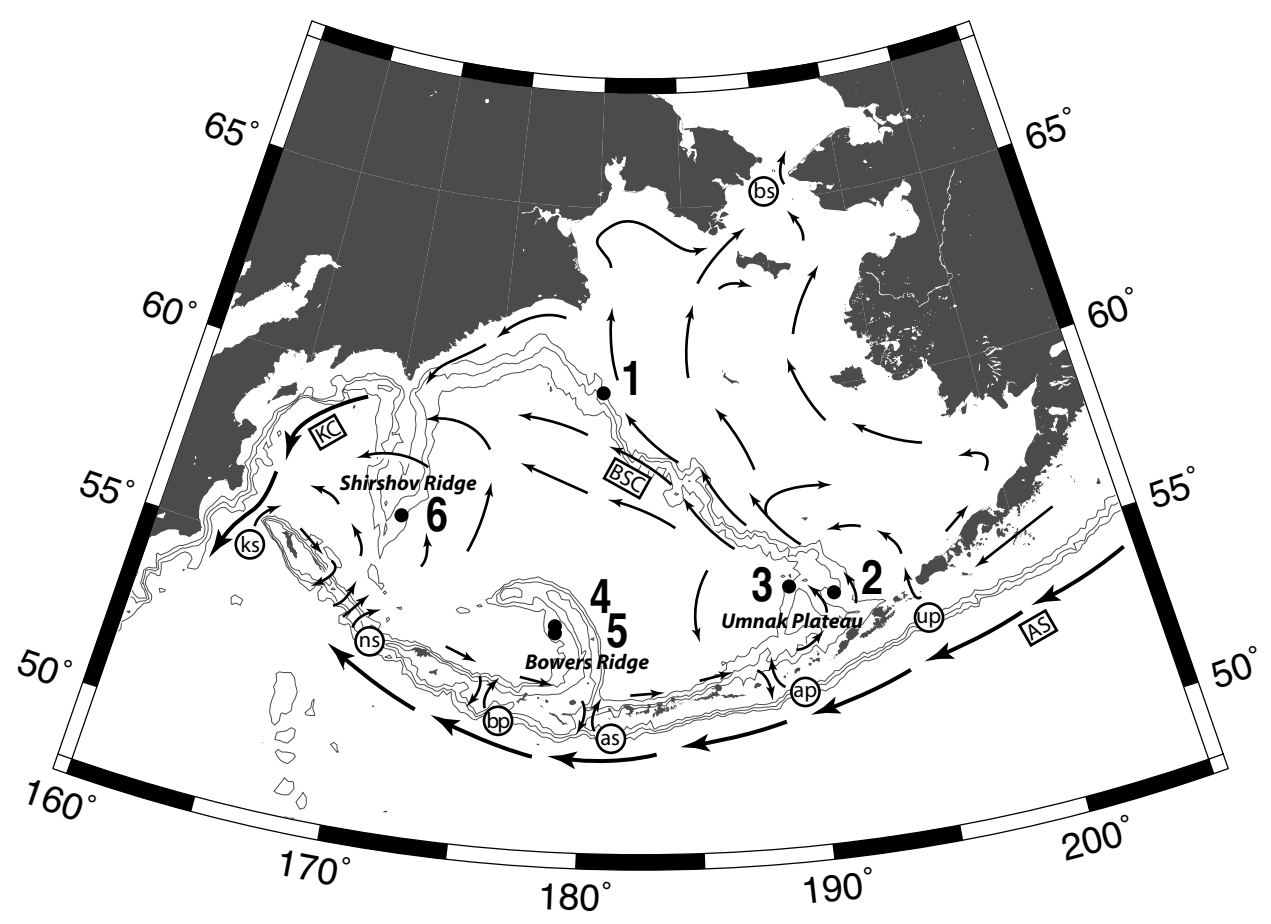

Fig. 1. Bering Sea core locations. Bathymetric contours are at $1 \mathrm{~km}, 2 \mathrm{~km}$, and $3 \mathrm{~km}$. Details of the numbered core locations are in Table 1. Mean surface circulation is indicated (modified from Stabeno et al. (1999)). Currents (rectangles) and geographic features (circles) referred to in the text are labeled: Kamchatka Current (KC), Bering Slope Current (BSC), Alaskan Stream (AS), Bering Strait (bs), Kamchatka Strait (ks), Near Strait (ns), Buldir Pass (bp), Amchitka Strait (as), Amutka Pass (ap), and Unimak Pass (up).

400-2000 m originates from mixing of NPIW with intermediate-depth water that originates from the south (Roden, 2000). Deeper than $2000 \mathrm{~m}$, compared to the North Pacific, Bering Sea water is slightly fresher, warmer, and enriched in nutrients, particularly silicate, which dissolves from opal-rich seafloor sediments (Roden, 2000). Consistent with the restricted exchange of the deepest Bering Sea water with the North Pacific, $\Delta^{14} \mathrm{C}$ is slightly lower than North Pacific water of equivalent depth (GEOSECS Executive Committee and Östlund, 1987).

There is a band of very high productivity along the BSC. Low stratification along the slope break is caused by tidal mixing and transverse circulation, bringing nutrients from $300-800 \mathrm{~m}$ depths to the surface and supporting production to high tropic levels (Springer et al., 1996). The OMZ in the Bering Sea is the most intense at $\sim 900 \mathrm{~m}$ water depth, with concentrations of dissolved oxygen $\left(\left[\mathrm{O}_{2}\right]\right)$ as low as $15 \mu \mathrm{mol} / \mathrm{kg}$ (Roden, 2000). 


\begin{tabular}{rrlcc} 
location & $\#$ & \multicolumn{1}{c}{ core } & depth & latitude/longitude \\
\hline Bering Slope & 1 & HLY02-02-3JPC & $1132 \mathrm{~m}$ & $\mathrm{~N} 60.1279^{\circ} / \mathrm{E} 180.5582^{\circ}$ \\
Umnak Plateau & 2 & HLY02-02-51JPC & $1467 \mathrm{~m}$ & $\mathrm{~N} 54.5532^{\circ} / \mathrm{E} 191.3331^{\circ}$ \\
Umnak Plateau & 3 & RC14-121 & $2532 \mathrm{~m}$ & $\mathrm{~N} 54.8500^{\circ} / \mathrm{E} 189.3233^{\circ}$ \\
Bowers Ridge & 4 & HLY02-02-17JPC & $2209 \mathrm{~m}$ & $\mathrm{~N} 53.9330^{\circ} / \mathrm{E} 178.6988^{\circ}$ \\
Bowers Ridge & 5 & VINO19-12GGC & $2745 \mathrm{~m}$ & $\mathrm{~N} 53.7367^{\circ} / \mathrm{E} 178.7083^{\circ}$ \\
Shirshov Ridge & 6 & ANTP-42PC & $2393 \mathrm{~m}$ & $\mathrm{~N} 56.3870^{\circ} / \mathrm{E} 171.0770^{\circ}$ \\
\hline
\end{tabular}

Table 1

The cores used in this study. HLY cores were collected in summer, 2002.

\section{Methods}

For stable isotope analysis, $0.5 \mathrm{~cm}$-thick (in laminated intervals) or $1 \mathrm{~cm}$ thick (in massive intervals) samples with dry mass of $1-5 \mathrm{~g}$ were taken every $12 \mathrm{~cm}$ in the HLY cores. Two-centimeter-thick samples were taken every $4 \mathrm{~cm}$ in VINO19-12GGC and every $5 \mathrm{~cm}$ in ANTP-42PC. Sediment samples were oven dried at $50^{\circ} \mathrm{C}$ then washed with tap water through a $63 \mu \mathrm{m}$ sieve. Benthic foraminifera were picked from the $>250 \mu \mathrm{m}$ fraction, planktonic from the $150-250 \mu \mathrm{m}$ fraction. Single tests of a hispid species of the benthic genus Uvigerina, and 8 tests of the planktonic species Neogloboquadrina pachyderma (sinistral) were analyzed from each sample on a VG PRISM-III mass spectrometer with an Isocarb system $\left(90^{\circ} \mathrm{C}\right.$ common acid bath) for $\delta^{18} \mathrm{O}$ with a precision of $\pm 0.07 \%$. Exceptions are HLY02-02-51JPC, where a costate Uvigerina species was used, and in VINO19-12GGC and ANTP-42PC where 15 N. pachyderma (s.) comprised each analysis. Uvigerina is not present in all samples. Percent $\mathrm{CaCO}_{3}$ was measured as in Keigwin et al. (1992). Methods for counting diatom species relative abundance are described in Sancetta et al. (1985). Diatom $\delta^{18} \mathrm{O}$ data and a lower resolution version of the diatom relative abundance data from RC14-121 were previously published in Sancetta et al. (1985).

Radiocarbon dating was performed at the National Ocean Sciences Accelerator Mass Spectrometry (NOSAMS) facility at WHOI on N. pachyderma (s.) $>150 \mu \mathrm{m}$. In calibrating our dates, we assumed the local anomaly from the mean global reservoir correction $(\Delta R)$ was constant at $300 \mathrm{y}$. The modern $\Delta \mathrm{R}$ in the North Pacific is not well known; estimates include 80-360 y in the northern and eastern Bering Sea (Dumond and Griffin, 2002), 320土40y at the Kuril Islands and 40 $40 \mathrm{y}$ in the Sea of Japan (Kuzmin et al., 2002), and $240 \pm 50$ y near Kamchatka Strait (Robinson and Thompson, 1981). It is very likely that $\Delta \mathrm{R}$ is spatially and temporally variable as a function of local up- 


\begin{tabular}{|c|c|c|c|c|}
\hline core & depth $(\mathrm{cm})$ & ${ }^{14} \mathrm{C}$ y $\mathrm{BP} \pm \sigma$ & y BP & \pm \\
\hline HLY02-02-3JPC & $140.5-142.5$ & $10,050 \pm 60$ & 10,340 & $\begin{array}{l}10,620 \\
10,300\end{array}$ \\
\hline HLY02-02-3JPC & $352.5-353.5$ & $10,850 \pm 65$ & 11,650 & $\begin{array}{l}11,920 \\
10,900\end{array}$ \\
\hline HLY02-02-3JPC & $600.5-601.5$ & $12,400 \pm 65$ & 13,500 & $\begin{array}{l}13,810 \\
13,470\end{array}$ \\
\hline HLY02-02-3JPC & $906.5-909.5$ & $13,350 \pm 80$ & 14,400 & $\begin{array}{l}15,360 \\
14,330\end{array}$ \\
\hline HLY02-02-51JPC & $134.5-135.5$ & $10,600 \pm 60$ & 11,250 & $\begin{array}{l}11,600 \\
10,850\end{array}$ \\
\hline HLY02-02-51JPC & $177.5-178.5$ & $12,500 \pm 60$ & 13,540 & $\begin{array}{l}13,830 \\
13,490\end{array}$ \\
\hline HLY02-02-51JPC & $241.5-242.5$ & $14,050 \pm 85$ & 15,920 & $\begin{array}{l}16,170 \\
15,680\end{array}$ \\
\hline HLY02-02-17JPC & $155.5-156.5$ & $10,000 \pm 60$ & 10,320 & $\begin{array}{l}10,600 \\
10,290\end{array}$ \\
\hline HLY02-02-17JPC & $185.5-186.5$ & $12,550 \pm 65$ & 13,590 & $\begin{array}{l}14,000 \\
13,490\end{array}$ \\
\hline HLY02-02-17JPC & $215.5-216.5$ & $13,400 \pm 60$ & 14,450 & $\begin{array}{l}15,420 \\
14,350\end{array}$ \\
\hline
\end{tabular}

Table 2

Uncorrected AMS ${ }^{14} \mathrm{C}$ ages measured on N. pachyderma (s.) and corrected, calibrated ages. Calibrations performed with Calib4.4html (Stuiver et al., 1998) using $\Delta \mathrm{R}=300 \mathrm{y}$, corresponding to a $\sim 700 \mathrm{y}$ reservoir correction. We report the maximum probability calendar ages with the upper and lower limits of the $1 \sigma$ range.

welling strength and circulation, so our assumed value of $300 \mathrm{y}$ should only be regarded as a reasonable guess. $\Delta \mathrm{R}$ may have varied by up to a few hundred years through time and between these sites, but this would not affect the conclusions of this paper.

\section{Results $^{1}$}

\subsection{Lithology}

All of our cores contain 1 or 2 deglacial intervals which are visually identified as high $\% \mathrm{CaCO}_{3}$, high $\%$ opal, and high $\% \mathrm{C}_{\mathrm{org}}$ intervals with a distinctly greenish hue. HLY02-02-3JPC contains the most expanded deglacial sequence of the cores in this study, at $\sim 8 \mathrm{~m}$ long, with an average sediment accumulation rate of $190 \mathrm{~cm} / \mathrm{ky}$ from the beginning to the end of the laminated sequences. There are 4 visibly laminated intervals, which are composed of pairs of dark and light olive laminae ranging in thickness from $<1 \mathrm{~mm}$ to $2 \mathrm{~mm}$ (Figure 2). Intervening massive intervals and the deepest $6 \mathrm{~m}$ of sediment are composed of

1 All data reported in this paper are posted on the NOAA Paleoclimatology Program website (http://www.ngdc.noaa.gov/paleo/paleo.html). 


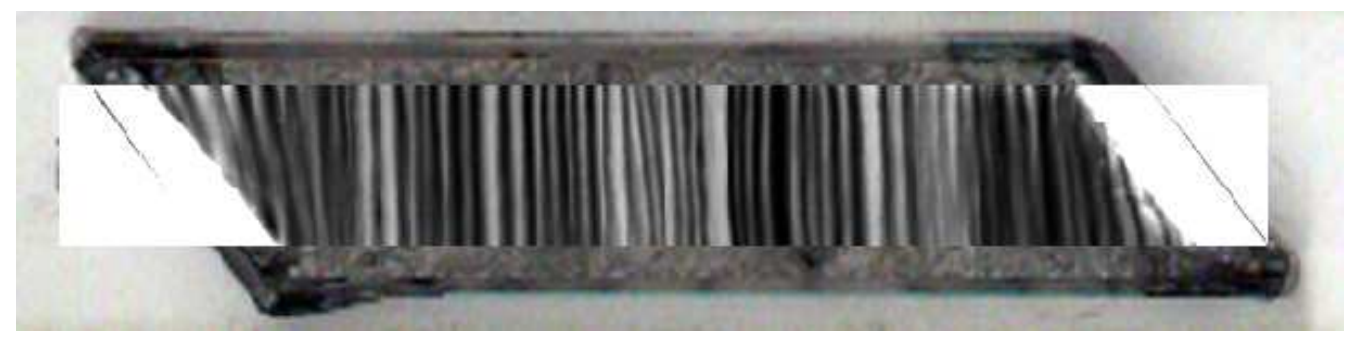

Fig. 2. Positive $\mathrm{x}$-radiograph of a u-channel sample taken from HLY02-02-1GGC $(255-267 \mathrm{~cm})$, a companion core to HLY02-02-3JPC. This $12 \times 2.5 \mathrm{~cm}$ sample is from a depth interval that is the equivalent of the uppermost laminated interval in HLY02-02-3JPC. From our estimates of sediment accumulation rate, each light-dark pair probably represents one year of accumulation. Note the cyclic variability in lamina thickness indicating sub-decadal variability in the seasonal deposition of sediment.

very fine grained sticky homogeneous dark olive-grey mud. The topmost $1.4 \mathrm{~m}$ of sediment is firm dark-olive-grey mud. Holocene sediments from the Bowers and Shirshov Ridges are diatomaceous and contain moderately high $\mathrm{CaCO}_{3}$. The sediment accumulation rates in HLY02-02-51JPC and HLY02-02-17JPC are $15-20 \mathrm{~cm} / \mathrm{ky}$ during the deglaciation. We currently have no age control for the Holocene portions of the HLY cores because of the rarity of planktonic foraminifera and the unknown amount of sediment lost from the top of piston cores during the coring process.

For the time interval corresponding to the deglaciation, stratigraphic correlation between the HLY cores is based on $10{ }^{14} \mathrm{C}$ dates, and in the other cores it is based on lithology. The upper and lower laminated intervals in HLY02-02-51JPC correspond to the upper 1 and lower 3 laminated intervals in HLY02-02-3JPC. In the other 4 cores, the analogs to the laminated sequence are the 1 or 2 "green layers," which are indicated with shaded bars in Figures 3 and 4 . For the cores with no age control, this correlation is approximate, assuming that green and laminated intervals represent contemporaneous dysaerobic conditions at the sediment-water interface. In RC14-121, three uncorrected, uncalibrated ${ }^{14} \mathrm{C}$ dates were measured on $20 \mathrm{~cm}$-thick sections of sediment and were interpreted by Sancetta et al. (1985) as maximum, not exact ages, establishing the uppermost lithological unit of this core $(0-175 \mathrm{~cm})$ as Holocene.

\subsection{Oxygen Isotope Data}

There are 2 rapid decreases of planktonic $\delta^{18} \mathrm{O}$ in HLY02-02-3JPC, at 888$924 \mathrm{~cm}$ and 348-372 cm (Figure 3) which occur at 14,400 y BP and 11,650 y BP, respectively. Linearly interpolating between the four ${ }^{14} \mathrm{C}$ dates, the transitions occur in $\leq 190 \mathrm{y}$ and $\leq 130 \mathrm{y}$ (Figure 3 ). The magnitude of the $\delta^{18} \mathrm{O}$ events is 

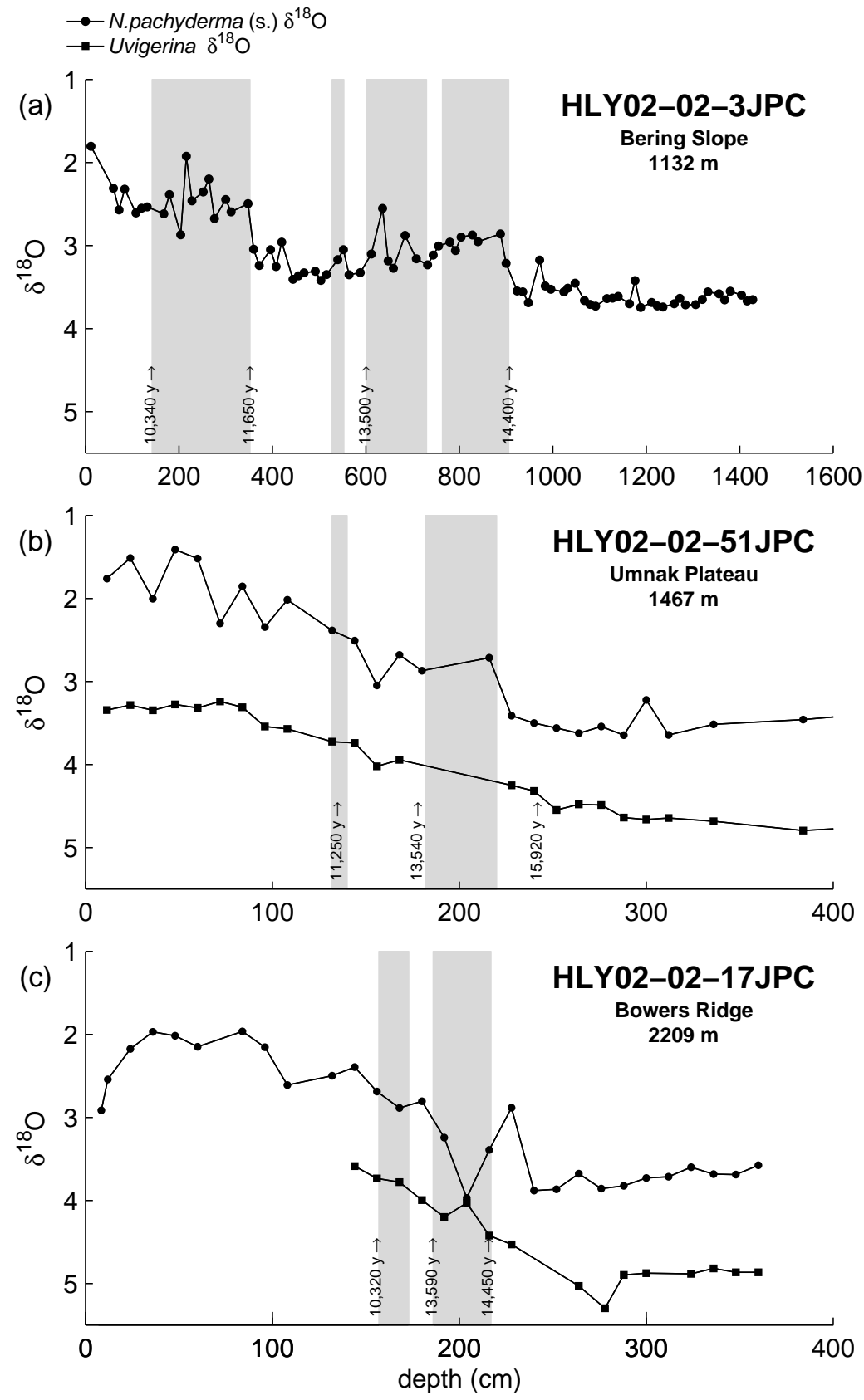

Fig. 3. Shaded bars represent "green" layers, which are characterized by high $\% \mathrm{CaCO}_{3}, \% \mathrm{C}_{\mathrm{org}}$, and \% opal. In (a) and (b), these layers are laminated, where the laminae are probably annual pairs (see text). $\delta^{18} \mathrm{O}$ data is of Uvigerina with costate test in (b), hispid test in (c). The ${ }^{14} \mathrm{C}$ dates in (a) are calibrated to calendar years (Table 2 ). The 2 abrupt $\sim 0.7-0.8 \%$ decreases in $\delta^{18} \mathrm{O}$ in panel (a) occur at 14,400 and 11,650 y BP, each event lasting at most $\sim 200$ y. Assuming direct correlation of the green layers between cores, the sediment accumulation rates range from $\geq 12 \mathrm{~cm} / \mathrm{ky}$ in (b) and (c) to $190 \mathrm{~cm} / \mathrm{ky}$ during the deglaciation in (a). Note that the $\mathrm{x}$-axis scales are not the same between the panels. 
$\sim 0.7-0.8 \%$. In RC14-121 and ANTP-42PC, the $\delta^{18} \mathrm{O}$ measurements begin probably after the start of the deglaciation since the highest benthic $\delta^{18} \mathrm{O}$ measurements in those cores are lower than the LGM values in similar-depth cores HLY02-02-17JPC and VINO19-12GGC, which are at $\sim 5 \%$. In RC14121 , there is a $\sim 1 \%$ decrease in benthic $\delta^{18} \mathrm{O}$ in adjacent samples at 170 $190 \mathrm{~cm}$ (Figure 4). In the rest of the Bering Sea cores, there are no robust features in foraminifer $\delta^{18} \mathrm{O}$ in the data currently available.

\subsection{Diatom Relative Abundance Data}

In Umnak Plateau core RC14-121 (Figure 4), the new data at closer sample spacing support the earlier observations of Sancetta et al. (1985). The sum of the abundances of the diatoms Nitzschia grunowii and Nitzschia cylindra (both sometimes assigned to Fragilariopsis) indicate the presence of sea ice. During the late glacial or early deglacial transition, these sea ice species occur at a relative abundance of $>20 \%$. There is a subsequent decrease in Nitzschia that is contemporaneous with a $\sim 9 \%$ decrease in bulk opal $\delta^{18} \mathrm{O}$. This is followed by a newly resolved increase in Nitzschia which occurs as the Uvigerina $\delta^{18} \mathrm{O}$ decreases. Nitzschia abundance from ANTP-42PC of Shirshov Ridge is low throughout the deglaciation, and is zero in each of the samples at VINO19-12GGC. The species Rhizosolenia hebetata, which indicates high nutrient availablilty and $\mathrm{C}_{\mathrm{O} g}$ flux, shows highest relative abundance during the green layers in ANTP-42PC. In RC14-121, R. hebetata shows no significant changes, with an average relative abundance of $\sim 3 \%$ through the deglaciation and Holocene.

\section{Discussion}

\subsection{Chronology and Correlations}

The sequence of Bering Sea laminated sediment is similar to the California Borderland Basins and Gulf of California, where laminations occur during the Holocene and the Bølling-Allerød (Keigwin and Jones, 1990; Behl and Kennett, 1996; Zheng et al., 2000; van Geen et al., 2003). Based on a simple age model where we linearly interpolate between the $4{ }^{14} \mathrm{C}$ dates, the 4 laminated intervals in HLY02-02-3JPC may correspond to (1) the Bølling, (2) the early Allerød, (3) the Allerød following the Inter-Allerød Cold Period, and (4) the early Holocene. This correlation will need confirmation from more detailed

${ }^{14} \mathrm{C}$ dating and a more robust estimate of the reservoir correction. From our 

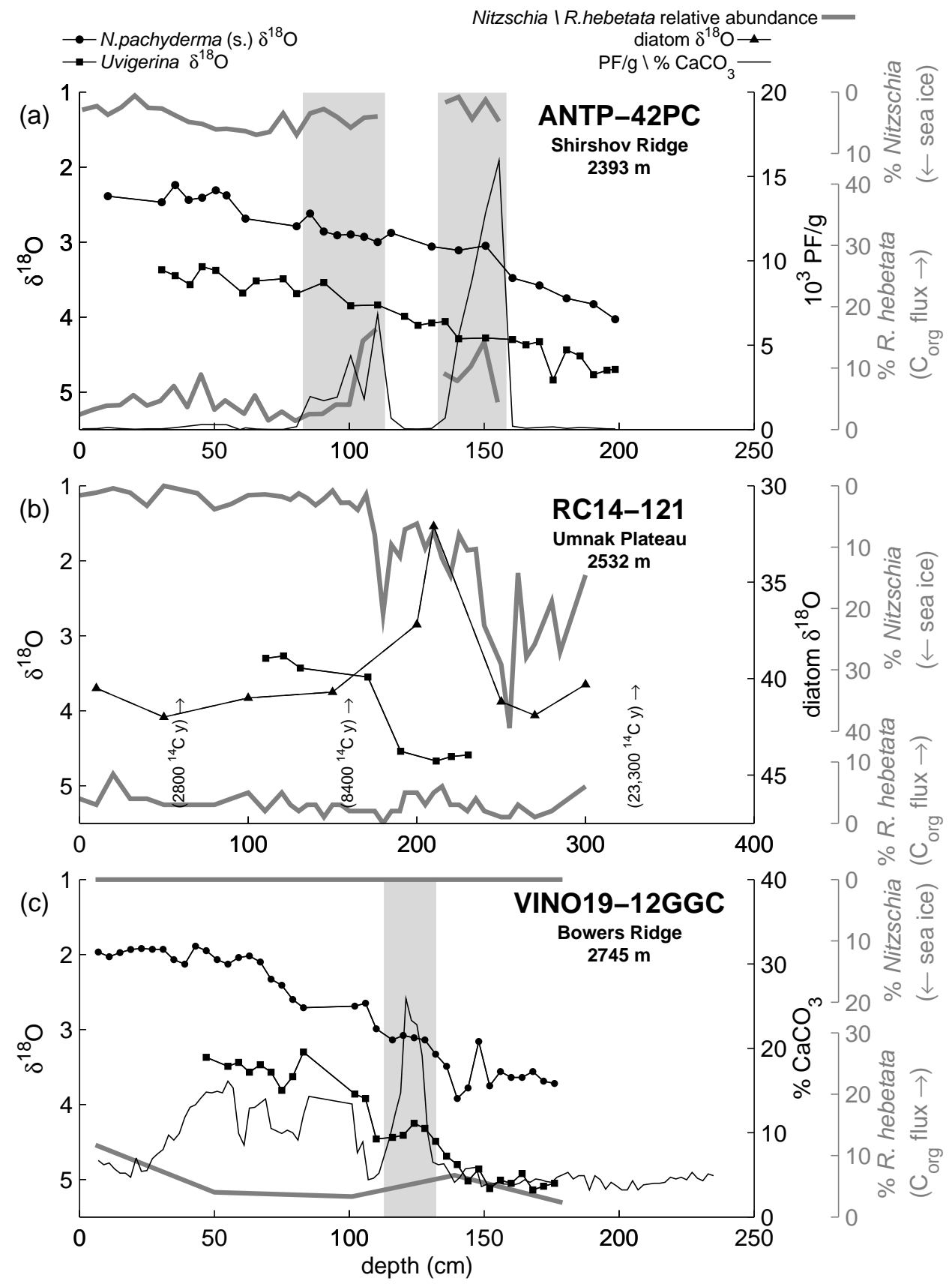

Fig. 4. Shaded bars represent "green" layers, which are characterized by high $\% \mathrm{CaCO}_{3}, \% \mathrm{C}_{\mathrm{org}}$, and \% opal. $\delta^{18} \mathrm{O}$ data is of Uvigerina with hispid test in (a), (b), and (c). The thin line in (c) is $\% \mathrm{CaCO}_{3}$, in (a) it is \# planktonic foraminifera (PF) per gram dry sediment, a proxy for $\% \mathrm{CaCO}_{3}$. Presence of Nitzschia is associated with sea ice, $R$. hebetata is associated with high nutrient availability and $\mathrm{C}_{\mathrm{org}}$ flux. Nitzschia abundance patterns show that maximum extent of sea ice may not have reached the Bowers or Shirshov Ridges core sites during the LGM or YD. Note that the $\mathrm{x}$-axis scales are not the same between the panels. The $\mathrm{y}$-axis scales for a property on each panel are identical. Previously reported in Sancetta et al. (1985) were the diatom $\delta^{18} \mathrm{O}$ data and the 3 uncorrected, uncalibrated ${ }^{14} \mathrm{C}$ dates in (b), which were measured on the organic fraction of $20 \mathrm{~cm}$-thick sections of sediment and interpreted as maximum, not exact ages, establishing the uppermost lithologic unit of this core $(0-175 \mathrm{~cm})$ as Holocene 11 
estimate of sediment accumulation rate and the lamina thickness, each lightdark pair probably represents one year of accumulation.

The lithology of the deglacial sequence in the Bering Sea is similar to that observed in cores from the Okhotsk Sea and Bering Sea (Gorbarenko, 1996) and the open North Pacific (Keigwin et al., 1992; Gorbarenko, 1996; Keigwin, 1998) where during the deglaciation, rapid decreases in planktonic foraminifer $\delta^{18} \mathrm{O}$ precede intervals of high $\% \mathrm{CaCO}_{3}$. Percent $\mathrm{C}_{\text {org }}$ and $\%$ opal are generally high during these intervals as well. From dry bulk density measurements and an estimate of sediment accumulation rate, Keigwin et al. (1992) determined that not only the percentage, but the fluxes of the biogenic components increased. This conclusion has received further support from accumulation rates calculated using the excess Th method (Crusius et al., 2004).

In cores from the far Northwest Pacific, Okhotsk Sea, and Bering Sea Gorbarenko (1996) determined that the negative planktonic $\delta^{18} \mathrm{O}$ events occurred at $12,500{ }^{14} \mathrm{C}$ y $\mathrm{BP}$ and $9,300{ }^{14} \mathrm{C}$ y $\mathrm{BP}$ using a 1100 y reservoir correction. Calibrated to calendar years using $\Delta \mathrm{R}=300 \mathrm{y}$, these become $15,400 \mathrm{y}$ BP and 11,100 y BP, respectively. Considering the difficulty in identifying the location of the $\delta^{18} \mathrm{O}$ events in cores with low sediment accumulation rates, these ages are reasonably close to our dating of the events in HLY02-02-3JPC as 14,400 y $\mathrm{BP}$ and $11,650 \mathrm{y}$ BP.

The deglacial $\delta^{18} \mathrm{O}$ decrease of $\sim 9 \%$ measured in diatom silica in RC14-121 is much larger than the foraminifer $\delta^{18} \mathrm{O}$ decreases measured in any of the other Bering Sea cores. As discussed in Sancetta et al. (1985), diatom $\delta^{18} \mathrm{O}$ is more sensitive to changes in surface hydrography than foraminifer $\delta^{18} \mathrm{O}$, and because of the magnitude of the event, it probably represents a freshening of surface water. If it was entirely due to warming, the diatom $\delta^{18} \mathrm{O}$ signal would represent a temperature increase of $\sim 18^{\circ} \mathrm{C}$ (calibration of Shemesh et al. (1992)), which is not probable. Sancetta et al. (1985) hypothesized that the source of the freshening was a large flux of meltwater from retreating alpine glaciers in Alaska.

Of the 3 study regions with diatom data, only the Umnak Plateau (RC14-121) has indications of significant change in sea ice in the past, with 2 maxima in Nitzschia at what appear to be the LGM and the YD. The Nitzschia maximum at $2.5 \mathrm{~m}$ is interpreted to represent extreme glacial conditions with sea ice cover throughout the year (Sancetta et al., 1985). Today, the maximum winter ice edge in the Bering Sea does not reach the Bowers Ridge, and just reaches the Umnak Plateau (Niebauer et al., 1999). No sea ice diatoms are present in any of the samples analyzed from the VINO19-12GGC (Bowers Ridge). Katsuki et al. (2003) report that abundance of Thalassiosira gravida suggests sea ice was proximate at the crest but not the western side of the Bowers Ridge at the LGM. Nitzschia is present at Shirshov Ridge core ANTP-42PC but in low 
abundance throughout the record. Percent $R$. hebetata is relatively high in the older green layer and at the base of the younger green layer, suggesting high $\mathrm{C}_{\mathrm{Org}}$ flux to the sediments when these layers were deposited. Numbers of planktonic foraminifera per gram dry sediment (a proxy for $\% \mathrm{CaCO}_{3}$ ) reach a peak in both the green layers at 1-2 orders of magnitude higher than in intervening sediments, so probably represent high $\mathrm{CaCO}_{3}$ flux at those times as well.

\subsection{What Produces the Laminated Sediment?}

Laminated sediments occur when the dissolved oxygen at the sediment-water interface is too low for burrowing macrofauna $\left(\left[\mathrm{O}_{2}\right] \leq 5 \mu \mathrm{M}\right)$. This can be caused by the intersection of an intense OMZ with the seafloor. It can also occur when the flux of $\mathrm{C}_{\text {org }}$ is so high that the oxygen at the bottom of the water column is consumed by respiration. A third mechanism is seasonal fall-out of matforming diatoms or bacteria which can form a thick enough layer to suffocate benthic macrofauna (see Kemp (1996)).

In cores from the low latitude eastern North Pacific during the deglaciation, there is an increase in the extent of laminations from north to south (Zheng et al., 2000), toward the low oxygen intermediate water end member from the equatorial upwelling region. Stott et al. (2000) and van Geen et al. (2003) document asynchrony of laminations in cores from the Pacific coast of California and Baja, highlighting the influence of local export production in the occurrence of laminated sediment. In the Bering Sea, despite its proximity to the source of well-oxygenated NPIW, the belt of high productivity in the BSC appears to have drawn $\left[\mathrm{O}_{2}\right]$ low enough to bring it near the $5 \mu \mathrm{M}$ threshold for laminae preservation.

A simple explanation for the contemporaneous sequences of laminated and dysaerobic sediments in widely separated regions of the North Pacific is that the primary control is the $\left[\mathrm{O}_{2}\right]$ of the large scale intermediate water mass and that flux of NPIW was reduced in the YD and other cold deglacial climate events. But anoxia caused by an increase in export production leaves a similar geochemical imprint in the sedimentary record, and there is evidence of higher fluxes of biogenic sedimentary components during the deglacial events. Based on data available at present, we cannot distinguish between the two hypotheses. It is likely that both processes are involved. 


\section{Conclusions}

(1) The deglacial lithology in the Bering Sea can be correlated to other parts of the North Pacific. The deglaciation is characterized by 1-2 "green layers," which are occasionally laminated.

(2) There is a widespread occurrence of laminated sediments in the North Pacific, from the well-documented California margin and Gulf of California anoxic basins to the continental slope of the Bering Sea. In one of our cores from the continental slope near the Pervenets Canyon, the laminations occur during the Bølling-Allerød and the early Holocene, which is similar to Behl and Kennett's (1996) findings in Santa Barbara Basin.

(3) The primary control on the presence of laminated sediments in the North Pacific could be the oxygen content of NPIW. But both ventilation and export production probably contribute to the dysaerobic conditions.

(4) Two abrupt freshening and/or warming events are recorded in planktonic foraminifer $\delta^{18} \mathrm{O}$ at $14,400 \mathrm{y} \mathrm{BP}$ and $11,650 \mathrm{y} \mathrm{BP}$ which directly precede the "green layers."

(5) There is a YD-like cold event in the Bering Sea region, which is expressed as a maximum of sea ice diatoms Nitzschia in a core from the Umnak Plateau.

\section{Acknowledgments}

We thank Mary R. Carman and Alan R. Gagnon for assistance preparing and analyzing stable isotope samples, the crew of the USCGC Healy for their contribution to the success of the Bering Sea cruise, the NOSAMS facility for expediting our radiocarbon samples, and Cox Analytical of Götheburg, Sweden, for providing the x-ray image. The Oak Foundation of Boston, Massachusetts, and the WHOI Academic Programs Office provided support for Mea Cook. This project was funded by NSF grant OPP-9912122. We thank Sergei Gorbarenko, Yusuke Okazaki, Kozo Takahashi, an anonymous reviewer, and Jerry McManus for helpful comments. Figure 1 was made with GMT (Wessel and Smith, 1998). This is WHOI contribution No. 11155.

\section{References}

Ahagon, N., Ohkushi, K., Uchida, M., Mishima, T., 2003. Mid-depth circulation in the northwest Pacific during the last deglaciation: evidence from foraminiferal radiocarbon ages. Geophysical Research Letters 30 (21), 2097, doi:10.1029/2003GL018287.

Andreev, A., Watanabe, S., 2002. Temporal changes in dissolved oxygen of the 
intermediate water in the Subarctic North Pacific. Geophysical Research Letters 29 (14), 10.1029/2000GL015021.

Behl, R. J., Kennett, J. P., 1996. Brief interstadial events in the Santa Barbara Basin, NE Pacific, during the past 60 kyr. Nature 379, 243-246.

Boyle, E. A., Keigwin, L. D., 1987. North Atlantic thermohaline circulation during the past 20,000 years linked to high-latitude surface temperture. Nature 330, 35-40.

Carlson, P. R., Karl, H. A., 1988. Development of large submarine canyons in the Bering Sea, indicated by morphologic, seismic, and sedimentologic characteristics. Geological Society of America Bulletin 100, 1594-1615.

Cooper, L. W., Witledge, T. E., Grebmeier, J. M., Weingartner, T., 1997. The nutrient, salinity, and stable oxygen isotope composition of Bering and Chukchi Seas waters in and near the Bering Strait. Journal of Geophysical Research 102 (C6), 12,563-12,573.

Crusius, J., Pedersen, T. F., Kienast, S., Keigwin, L., Labeyrie, L., 2004. Influence of northwest pacific productivity on north pacific intermediate water oxygen concentrations during the bølling-ållerød interval (14.7-12.9 ka). Geology 32 (7), 633-636.

Dumond, D. E., Griffin, D. G., 2002. Measurements of the marine reservoir effect on radiocarbon ages in the eastern Bering Sea. Arctic 55 (1), 77-86.

Elias, S. A., Short, S. K., Birks, H. H., 1997. Late Wisconsin environments of the Bering Land Bridge. Palaeogeography, Palaeoclimatology, Palaeoecology 136, 293-308.

Emile-Geay, J., Cane, M. A., Naik, N., Seager, R., Clement, A. C., van Geen, A., 2003. Warren revisited: atmospheric freshwater fluxes and "Why is no deep water formed in the North Pacific". Journal of Geophysical Research 108 (C6), 3178, doi:10.1029/2001JC001058.

GEOSECS Executive Committee, Östlund, H. G., 1987. Shorebased Data and Graphics. Vol. 7 of GEOSECS Atlantic, Pacific, and Indian Ocean expeditions. National Science Foundation.

Gorbarenko, S. A., 1996. Stable isotope and lithologic evidence of late-glacial and Holocene oceanography of the northwestern Pacific and its marginal seas. Quaternary Research 46, 230-250.

Herguera, J. C., Jansen, E., Berger, W. H., 1992. Evidence for a bathyal front at $2000 \mathrm{~m}$ depth in the glacial Pacific, based on a depth transect on Ontong Java Plateau. Paleoceanography 7 (3), 273-288.

Hill, K. L., Weaver, A. J., Freeland, H. J., Bychkov, A., 2003. Evidence of change in the Sea of Okhotsk: implications for the North Pacific. Atmosphere-Ocean 41 (1), 49-63.

Joyce, T. M., Dunworth-Baker, J., 2003. Long-term hydrographic variability in the Northwest Pacific Ocean. Geophysical Research Letters 30 (2), 1043, doi:10.1029/2002GL015225.

Katsuki, K., Takahashi, K., Jordan, R. W., Matsushita, K., Sengoku, T., 2003. Surface circulation changes based on fossil diatoms in the bering sea and the western subarctic pacific. Kaiyo Monthly 35, 394-400. 
Keigwin, L. D., 1998. Glacial-age hydrography of the far Northwest Pacific Ocean. Paleoceanography 13 (4), 323-339.

Keigwin, L. D., Jones, G. A., 1990. Deglacial climatic oscillations in the Gulf of California. Paleoceanography 5 (6), 1009-1023.

Keigwin, L. D., Jones, G. A., Froelich, P. N., 1992. A 15,000 year paleoenvironmental record from Meji Seamount far northwestern Pacific. Earth and Planetary Science Letters 111, 425-440.

Kemp, A. E. S., 1996. Laminated sediments as palaeo-indicators. In: Kemp, A. E. S. (Ed.), Palaeoclimatology and Palaeoceanography from Laminated Sediments. The Geological Society, pp. vii-xii.

Kuzmin, Y. V., Burr, G. S., Jull, A. J. T., 2002. Radiocarbon reservoir correction ages in the Peter the Great Gulf, Sea of Japan, and eastern coast of the Kunashir, Southern Kuriles (Northwestern Pacific). Radiocarbon 43, 477-481.

Lund, D. C., Mix, A. C., 1998. Millennial-scale deep water oscillations: reflections of the North Atlantic in the deep Pacific from 10 to 60 ka. Paleoceanography 13, 10-19.

Macdonald, A. M., Suga, T., Curry, R. G., 2001. An isopycnally averaged North Pacific climatology. Journal of Atmospheric and Oceanic Technology $18,394-420$.

Matsumoto, K., Oba, T., Lynch-Stieglitz, J., Yamamoto, H., 2002. Interior hydrography and circulation of the glacial Pacific Ocean. Quaternary Science Reviews 21, 1693-1704.

McManus, J. F., Francois, R., Gherardi, J.-M., Keigwin, L. D., Brown-Leger, S., 2004. Collapse and rapid resumption of Atlantic meridional circulation linked to deglacial climate changes. Nature 428, 834-837.

Morley, J. J., Robinson, S. W., 1986. Improved method for correlating late Pleistocene/Holocene records from the Bering Sea: application of a biosiliceous geochemical stratigraphy. Deep-Sea Research I 33 (9), 12031211.

Niebauer, H. J., Bond, N. A., Yakunin, L. P., Plotnikov, V. V., 1999. An update on the climatology and sea ice of the Bering Sea. In: Loughlin, T. R., Ohtani, K. (Eds.), Dynamics of the Bering Sea. University of Alaska Sea Grant, AK-SG-99-03, pp. 29-59.

Ortiz, J. D., O'Connell, S. E., DelViscio, J., Dean, W., Carriquiry, J. D., Marchitto, T., Zheng, Y., van Geen, A., 2004. Enhanced marine productivity off western North America during warm climate intervals of the past $52 \mathrm{kyr}$. Geology, in press.

Robinson, S. W., Thompson, G., 1981. Radiocarbon corrections for marine shell dates with application to southern Pacific Northwest Coast prehistory. Syesis 14, 45-57.

Roden, G. I., 1995. Aleutian Basin of the Bering Sea: thermohaline, oxygen, nutrient, and current structure in July 1993. Journal of Geophysical Research 100 (C7), 13,539-13,554.

Roden, G. I., 2000. Flow and water property structures between the Bering Sea 
and Fiji in the summer of 1993. Journal of Geophysical Research 105 (C12), $28,595-28,612$.

Sancetta, C., Heusser, L., Labeyrie, L., Naidu, A. S., Robinson, S. W., 1985. Wisconsin-Holocene paleoenvironment of the Bering Sea: evidence from diatoms, pollen, oxygen isotopes and clay minerals. Marine Geology 62, 55-68.

Sancetta, C., Robinson, S. W., 1983. Diatom evidence on Wisconsin and Holocene events in the Bering Sea. Quaternary Research 20, 232-245.

Schumacher, J. D., Stabeno, P. J., 1998. The continental shelf of the Bering Sea. In: Robinson, A. R., Brink, K. H. (Eds.), The Global Coastal Ocean: Regional Studies and Synthesis. Vol. XI of The Sea. John Wiley and Sons, pp. 789-823.

Shemesh, A., Charles, C. D., Fairbanks, R. G., 1992. Oxygen isotopes in biogenic silica: global changes in ocean temperature and isotopic composition. Science 256, 1434-1436.

Springer, A. M., McRoy, C. P., Flint, M. V., 1996. The Bering Sea Green Belt: shelf-edge processes and ecosystem production. Fisheries Oceanography $5(3 / 4), 205-223$.

Stabeno, P. J., Schumacher, J. D., Ohtani, K., 1999. The physical oceanography of the Bering Sea. In: Loughlin, T. R., Ohtani, K. (Eds.), Dynamics of the Bering Sea. University of Alaska Sea Grant, AK-SG-99-03, pp. 1-29.

Starratt, S. W., 1993. Late Quaternary paleoceanography of the Pervenets Canyon area of the Bering Sea: evidence from the diatom flora. Diatom Research 8 (1), 159-170.

Starratt, S. W., 1995. Latest Quaternary foraminifers and sediment transport in Pervenets Canyon, Bering Sea. Marine Micropaleontology 26, 233-243.

Stott, L. D., Berelson, W., Douglas, R., Gorsline, D., 2000. Increased dissolved oxygen in Pacific intermediate waters due to lower rates of carbon oxidation in sediments. Nature 407, 367-370.

Stuiver, M., Reimer, P., Bard, E., Beck, J., Burr, G., Hughen, K., Kromer, B., McCormac, G., van der Plicht, J., Spurk, M., 1998. INTCAL98 Radiocarbon Age Calibration, 24000-0 cal BP. Radiocarbon 40 (3), 1041-1083.

Talley, L. D., 2003. Shallow, intermediate, and deep overturning components of the global heat budget. Journal of Physical Oceanography 33, 530-560.

van Geen, A., Zheng, Y., Bernhard, J. M., Cannariato, K. G., Carriquiry, J., Dean, W. E., Eakins, B. W., Pike, J., 2003. On the preservation of laminated sediments along the western margin of North America. Paleoceanography 18 (4), 1098, doi:10.1029/2003PA000911.

Vidal, L., Labeyrie, L., Cortijo, E., Arnold, M., Duplessy, J.-C., Michel, E., Becqué, S., van Weering, T., 1997. Evidence for changes in the North Atlantic Deep Water linked to meltwater surges during the Heinrich events. Earth and Planetary Science Letters 146, 13-27.

Warner, M. J., Roden, G. I., 1995. Chlorofluorocarbon evidence for recent ventilation of the deep Bering Sea. Nature 373, 409-412.

Warren, B. A., 1983. Why is no deep water formed in the North Pacific? Journal of Marine Research 41, 327-347. 
Wessel, P., Smith, W. H. F., 1998. New, improved version of Generic Mapping Tools released. EOS Transactions of the American Geophysical Union 79 (47), 579.

Yasuda, I., 1997. The origin of the North Pacific Intermediate Water. Journal of Geophysical Research 102 (C1), 893-909.

You, Y., 2003. Implications of cabbeling on the formation and transformation mechanism of North Pacific Intermediate Water. Journal of Geophysical Research C5, 3134, doi:10.1029/2001JC001285.

Zahn, R., Schönfeld, J., Kudrass, H.-R., Park, M.-H., Erlenkeuser, H., Grootes, P., 1997. Thermohaline instability in the North Atlantic during meltwater events; stable isotope and ice-rafted detritus records from core SO75-26KL, Portuguese margin. Paleoceanography 12, 696-710.

Zheng, Y., van Geen, A., Anderson, R. F., Gardner, J. V., Dean, W. E., 2000. Intensification of the Northeast Pacific oxygen minimum zone during the Bølling-Allerød warm period. Paleoceanography 15 (5), 528-536.

Zhuze, A. P., 1962. Stratigraficheskie i paleogeograficheskie issledovaniia v severo-zapadnol̆ chasti Tikhogo okeana. Izdatel'stvo Akademii Nauk SSSR. 